\title{
USING THE BSC FOR STRATEGIC PLANNING OF IT (INFORMATION TECHNOLOGY) IN BRAZILIAN ORGANIZATIONS
}

\author{
Adriano Olímpio Tonelli \\ Instituto Federal de Educação, Ciência e Tecnologia de Minas Gerais, Formiga, MG, \\ Brasil \\ Paulo Henrique de Souza Bermejo \\ André Luiz Zambalde \\ Universidade Federal de Lavras, Lavras/MG, Brasil
}

\section{ABSTRACT}

This paper presents a method that integrates Balanced Scorecard (BSC) concepts and IT strategic planning (ITSP) processes. The resulting method was applied in two organizations in order to verify contributions of Balanced Scorecard regarding the identified ITSP problems. The development of this work was realized in qualitative, exploratory research based on two case studies. The results show that the use of BSC contributed directly to work with IT strategic planning challenges and involved middle management, multifunctional teams, and top management support, all beyond IT boundaries.

Keywords: information technology strategic planning; balanced scorecard; information system management; IT strategic management; IT strategic alignment.

Manuscript first received/Recebido em: 17/05/2012 Manuscript accepted/Aprovado em: 05/02/2014

Address for correspondence / Endereço para correspondência

Adriano Olímpio Tonelli, Professor do Instituto Federal de Educação, Ciência e Tecnologia de Minas gerais, doutorando em Administração pela Universidade Federal de Lavras (UFLA). Possui mestrado em Administração, graduação em Ciência da Computação e MBA em Governança de TI, pela UFLA. Atua em atividades de pesquisa nas áreas de sistemas de informação, inovação, desenvolvimento de software e gestão estratégica de TI. E-mail: tonelli@dcc.ufla.br

Paulo Henrique S. Bermejo, professor adjunto do Departamento de Ciência da Computação da Universidade Federal de Lavras (UFLA). Formado na área de computação, Paulo Henrique realizou pós-doutorado na Universidade de Bentley (EUA), e doutorado em Engenharia e Gestão do Conhecimento pela Universidade Federal de Santa Catarina. Atua em atividades de pesquisa e ensino nas páreas de sistemas de informação, inovação e gestão estratégica de TI. E-mail: bermejo@dcc.ufla.br

André Luiz Zambalde, Professor Associado da Universidade Federal de Lavras-MG (UFLA), nos Departamentos de Ciência da Computação e Administração. É Engenheiro de Telecomunicações (INATEL-MG 1984). Pós-graduado em Administração (UFLA-MG 1989), Mestre em Eletrônica (UNIFEI-MG 1991), Doutor em Engenharia de Sistemas e Computação (COPPE/UFRJ 2000), com Pos-Doutorado em Ciência da Computação (UFMG-MG 2005) e Estatística e Gestão da Informação (UNINOVA - Portugal PT 2010). E-mail: zamba@ dcc.ufla.br 


\section{INTRODUCTION}

The strategic use of IT resources has recently attracted increased interest from researchers and organizations. Information technology (IT) has been established in the business world as a fundamental factor for corporate strategy development and realization (Gutierrez \& Serrano, 2008). However, ensuring that IT investments and initiatives deliver better performance and value to corporate strategies has become the main challenge for IT and business executives (Gutierrez \& Serrano, 2008; Lee \& Bai, 2003).

Based on this tendency in information technology in organizations, researchers (Grover \& Segars, 2005; Lederer \& Salmela, 1996; Lutchen, 2004; Mentzas, 1997; Min, Suh, \& Kim, 1999) have proposed and applied IT strategic planning methods. The adoption of ITSP methods and techniques has provided many benefits for organizations. These methods and techniques provide ways to develop a planning structure, improve the relationships between business and IT, support an identification of risks and threats, and allow strategies for evaluation and review (Cerpa \& Verner, 1998). ITSP methods are essential for aligning IT and organizational strategies in a way that enhances competitive advantages, creates market opportunities, provides direction, and concentrates efforts (Boar, 1994; Lee \& Pai, 2003; Newkirk, L., \& Srinivasan, 2003; Pai, 2006). However, in practice, promoting the effectiveness of IT strategic planning has been a major challenge to executives (Bechor, Neumann, Zviran, Chanan, \& 2010;(Lee \& Bai, 2003). As a result, IT strategic planning processes have faced many problems. According to Boar (1994), IT has historically made strategic plans that are either completely or partially devoid of respect within these business goals or with general organizational contexts. Previous surveys have found that more than half of all ITSP-involved stakeholders are not satisfied with the results (Bechor, et al., 2010).

The proliferation of the web and internet as business platforms, the outsourcing of IT resources and services, service-oriented architectures, cloud computing, and IT pervasiveness tend to expand ITSP development activities, which then creates new challenges to IT strategic planning (Grover \& Segars, 2005).

Many other challenges and deficiencies associated with ITSP development have been identified in the literature. Major challenges associated with IT strategic planning include stiffness of the applied methods (Lederer \& Salmela, 1996; Salmela \& Spil, 2002), difficulty in applying complex methodology (Grover \& Segars, 2005; Lederer \& Sethi, 2003; Salmela \& Spil, 2002; Segars \& Grover, 1998), a lack of support from top management on ITSP execution and IT strategic implementation (Lederer \& Sethi, 2003), excessive focus on IT functions inside specific aspects (Heckman, 2003), appropriated involvement of middle-level managers (Heckman, 2003), low participation of multifunctional teams (Earl, 2003; Huang \& Hu, 2007), distance and low relationship levels between formulation process (planning) and strategies implementation (Broady-Preston \& Hayward, 1998; Lederer \& Sethi, 2003; Littler, Aisthorpe, Hudson, \& Keasey, 2000), and a lack of learning and knowledge emphasis (Bermejo, Tonelli, Brito, \& Zambalde, in press; Lederer \& Salmela, 1996; Lee \& Pai, 2003; Pai, 2006). 
As IT departments have faced these challenges to develop the ITSP, Balanced Scorecard (Kaplan \& Norton, 1997) has been changing and consolidating as an important tool for strategic management (Kaplan \& Norton, 2008), including IT strategy development and implementation (Huang \& Hu, 2007; Simon, 2011).

Keyes (2005) highlights that, to promote a better alignment, a BSC must be intimately attached to an IT strategic planning process. This integration must extend beyond the simple capability of balanced scorecard in measuring improvements in IT. Despite the importance attached to ITSP development (Keyes, 2005), the Balanced Scorecard has not been extensively explored in IT strategic planning methods currently available in the literature. Balanced scorecard applications in IT function include BSC utilization as a mechanism to support the implementation of IT strategies (Littler, et al., 2000), promote IT-business strategic alignment and better communication (Huang \& $\mathrm{Hu}, 2007$ ), and conduct IT performance analysis (Velcu, 2010). In addition, other works focus on personalized structure development for IT balanced scorecards (Van Grembergen \& De Haes, 2005) and general IT BSC development orientations (Niven, 2002).

Studies that consider Balanced Scorecard application for short-, medium-, and long-term planning, including IT strategy formulations, have not been addressed in the literature. Additionally, in the broader context of ITSP studies, according to Grover and Segars (2005), only a few studies have emphasized questions about how to develop ITSP from a BSC perspective through a defined process, including planning process comprehension and whether it provides satisfactory results for an organization. This work aims to investigate the integration between ITSP and BSC in order to mitigate problems in IT strategic planning initiatives. Of these problems, we highlight the lack of support from top management (Lederer \& Sethi, 2003), excessive focus on specific aspects of IT functions (Earl, 2003), the need for ITSP expansion over frontiers (Grover \& Segars, 2005), low involvement of middle and top management (Lederer \& Sethi, 2003), and infrequent use of multidisciplinary teams (Earl, 2003).

This paper is organized as follows. Section 2 includes the paper's methodology. Section 3 shows the ITSP-BSC method. Section 4 summarizes the results obtained with the application of the proposed method in two organizations and then discusses the findings of this application. Finally, Section 5 describes conclusions, research limitations, and proposals for future works.

\section{METHODOLOGY}

This study integrates the concepts of Balanced Scorecard (Kaplan \& Norton, 1997; Keyes, 2005; Niven, 2002; Van Grembergen \& De Haes, 2005) and IT strategic planning (Bechor, et al., 2010; Bermejo, et al., 2012; Boar, 1994; Broady-Preston \& Hayward, 1998; Earl, 2003; Grover \& Segars, 2005; Lederer \& Sethi, 2003; Lee \& Bai, 2003; Littler, et al., 2000; Newkirk, et al., 2003; Pai, 2006; Salmela \& Spil, 2002; Segars \& Grover, 1998). The integration between BSC and ITSP was obtained using a deductive manner (Gimbel, 1968), which resulted in an ITSP-BSC method. This method was used to empirically examine two organizations, and the examination was based on qualitative data collected during the implementation of the proposed method. 
Therefore, the research can be characterized as exploratory, based on qualitative and longitudinal data, and conducted within a case study approach (Jung, 2004; Yin, 2005).

The data was collected from a semi-structured questionnaire, participant observation, and focus groups. These activities were performed by student teams from a graduate program of business education who were trained, oriented, and led by the authors.

The selection of the organizations was judgmental (Jung, 2004). The criteria followed the organization's top management interests and their availability in providing conditions for the case study implementation. In addition, we selected organizations that have a prior corporate BSC.

\section{THE REFERENCE ITSP METHOD}

To develop the proposed method, specific studies about ITSP, IT Governance and Management and Balanced Scorecard were considered. The ITSP studies considered were Boar (1994), Lederer and Salmela (1996), Lutchen (2004), and Bermejo et al. (2012). The ITSP phases proposed by Bermejo et al. (2012) were used as a reference to the structure of the proposed method. This choice was made considering that the method proposed in Bermejo et al. (2012) is aligned with IT Governance features and practices and shows a systematic structure that made possible to incorporate BSC practices in ITSP. In addition, the IT governance framework of Cobit (ITGI, 2007) was utilized.

The proposed method is structured in five phases: (1) IT alignment to business; (2) capacity and performance evaluation; (3) IT strategic planning; (4) IT tactic planning; and (5) ITSP results on socialization and closure.

In phase 1, IT visions and IT goals are defined for the organization. In phase 2, IT performance and capability for addressing the defined IT goals are evaluated. In this phase, the IT resources and critical processes are identified and analyzed. Conducting phases 1 and 2 makes it possible to identify gaps between current IT capabilities and future directions for strategic IT use in the organization. In phase 3, strategic actions are defined to narrow the gaps between current capabilities and future directions. In this phase, performance indicators are also developed to measure the performance of IT strategic actions. In phase 4, IT tactical projects are developed to implement the IT strategic actions defined in phase 3. In this phase, an IT strategic portfolio is developed. Finally, in phase 5, the results are shared with the stakeholders.

\section{BSC application in the ITSP method}

The following BSC concepts and practices were incorporated into the previously presented IT strategic planning process: 1) balanced perspectives to translate IT vision into IT goals and indicators; 2) strategic maps to establish cause-and-effect relationships among IT goals; and 3) performance vector indicators and results indicators. Additionally, alternative concepts and perspectives proposed for BSC application for information technology were used. Balanced perspectives developed by Van Grembergen and De Haes (2005) for an IT BSC-corporate contribution, user, 
operational excellence, and future orientation-were incorporated as an alternative to Kaplan and Norton's (1997) traditional perspectives - financial, customer, internal, and learning and growth. An IT BSC cascade was also incorporated during phase 1 to define the IT BSC aligned with corporate strategies.

Table 1 shows results provided for IT BSC incorporation along method phases.

Table 1. IT BSC evolution through the proposed method

\begin{tabular}{|l|l|}
\hline Phase & BSC-related activities incorporated into the ITSP method \\
\hline 1 & $\begin{array}{l}\text { IT BSC initial development; IT vision and goals definition according to } \\
\text { different perspectives in an IT BSC }\end{array}$ \\
\hline 2 & $\begin{array}{l}\text { SWOT analysis and analysis of IT critical processes' maturity, based on } \\
\text { thematic defined by the balanced perspectives in the IT BSC }\end{array}$ \\
\hline 3 & $\begin{array}{l}\text { IT BSC increment; inclusion of strategic actions and performance indicators } \\
\text { development }\end{array}$ \\
\hline $\begin{array}{l}\text { Strategic maps development: inclusion of cause and effect relations between } \\
\text { IT goals and performance vector and result }\end{array}$ \\
\hline 4 & $\begin{array}{l}\text { IT BSC increment; inclusion of projects and strategic services development } \\
\text { for IT strategic portfolio composition }\end{array}$ \\
\hline 5 & IT BSC release to the organization \\
\hline
\end{tabular}

During the first phase, activities were carried out in order to develop an initial IT BSC structure. These processes were based on the business goals, corporate BSC, and indicators to translate an IT vision into different relevant perspectives that could then be related by IT. An IT vision is represented in different perspectives. It is presupposed that the use of balanced perspectives to describe IT goals can1) direct ITSP activities over IT frontiers; 2) encourage top management and business unit members' involvement and 3) create the bases for multifunctional teams' development for ITSP conduction. Through the use of balanced perspectives, it is necessary to identify and analyze strategic IT demands from different organization units, including financial and billing issues, customer relationships, and internal processes in order to support continuous business growth and sustainability.

In phase 2, the balanced perspectives defined in phase 1 are used to drive the points to be considered in the evaluation of IT strategic questions, considering aspects inside and outside the organization. It is presupposed that the perspectives incorporated in phase 1 can direct the analysis of IT concerns in different organizational units, thus involving1) top management members to provide information relevant to IT capacity in attending costs, budget, and revenue goals; 2) organizational unit members-IT customers and users - to provide demands for strategic IT support to critical business processes; and

3) IT staff to demand IT internal capacity in terms of staff, IT service delivery, and support. In phase 3, strategic indicators and strategic maps are included in the BSC. In phase 4, an IT portfolio is included. Finally, in phase 5, the IT BSC is released to the organization. 
Through the incorporation of strategies and indicators organized on strategic maps, it is presupposed that the proposed method can contribute to a better synergy between IT and other business strategic units. This assumption is based on the potential of strategic maps to establish dependency between IT internal issues (internal perspective), sustainability and capacitating (learning and growing perspective), customers' IT demands (customer perspective), and owners and or shareholders (financial perspective).

\section{APPLYING THE PROPOSED METHOD}

The method was applied to two organizations from different sectors, one from the pharmaceutical sector and another from the health sector. The empirical results will be presented by summarizing the results of each phase of the method in each organization studied.

\section{Organization Alpha}

Organization Alpha operates in the pharmaceutical sector. The organization is 45 years old and has a portfolio of 240 products. In the 2000s, the organization adopted expansion for generic drug lines as the main direction for the business. Based on this vision, the organization's focus turned to the creation of productive expansion, aiming to facilitate the increase of products' quality.

Phase 1: IT-business alignment. Through the method application in Organization Alpha, it was possible to develop, during phase 1, the IT BSC initial structure with an IT vision related to efficient responsiveness and business growth support.

During phase 1, which involved the strategic committee, commercial director, industrial director, and administrative director, it was possible to define1) the strategic orientation for business expansion aligned to increased quality in the products, and2) specific directions related to planning, production, and quality control. Therefore, production and quality control were defined as the two areas in which IT needed to provide strategic support.

Table 2 illustrates the involvement of stakeholders - top management, strategic areas and IT managers - at the development of the IT BSC initial version, as well as the results obtained from this involvement. 
Table 2. Stakeholders' involvement on IT BSC initial version development in Organization Alpha

\begin{tabular}{|l|l|l|}
\hline Event & $\begin{array}{l}\text { Stakeholders } \\
\text { involved }\end{array}$ & Results \\
\hline Startup meeting & $\begin{array}{l}\text { IT + top } \\
\text { management }\end{array}$ & $\begin{array}{l}\text { Strategic priority: business expansion and } \\
\text { increase in quality } \\
\text { Strategic areas: planning, production, and } \\
\text { quality control }\end{array}$ \\
\hline IT vision & $\begin{array}{l}\text { Top management }+ \\
\text { strategic areas + IT }\end{array}$ & $\begin{array}{l}\text { To become a responsive sector to support } \\
\text { business expansion. }\end{array}$ \\
\hline IT goals & $\begin{array}{l}\text { Top management }+ \\
\text { IT }\end{array}$ & $\begin{array}{l}\text { Financial perspective: } \\
\text { Efficiency in IT expenditures and support } \\
\text { to business expansion and product quality }\end{array}$ \\
\cline { 2 - 3 } & $\begin{array}{l}\text { Organizational areas } \\
+ \text { IT }\end{array}$ & $\begin{array}{l}\text { Customer perspective: } \\
\text { Guarantee responsiveness to production } \\
\text { and quality control demands relative to } \\
\text { raw material sampling and weighing } \\
\text { Improve quality control through IT } \\
\text { solutions }\end{array}$ \\
\cline { 2 - 4 } & $\begin{array}{l}\text { Organizational areas } \\
+ \text { IT }\end{array}$ & $\begin{array}{l}\text { Internal perspective: } \\
\text { 4. Optimize IT services delivery and IT } \\
\text { infrastructure } \\
\text { Learning and growth perspective: } \\
\text { 5. IT capacitating in strategic } \\
\text { competences: production and quality }\end{array}$ \\
\hline
\end{tabular}

Based on the IT vision, it was possible to define the IT goals in different balanced scorecard perspectives.

Phase 2: Capacity and performance analysis. Based on the initial BSC structure, the following themes were defined to guide the capacity and performance analysis: 1) cost controlling process (financial perspective); 2) IT services in attending to quality control and production processes (customers' perspective); 3) IT internal organization (internal perspective); 4) IT teams' competence in production process, quality control, and financial management, and 5) top management competence on IT demand identification and analysis (learning and growth perspective).

Table 3 shows a sample of the SWOT analysis conducted in Organization Alpha, considering the main weaknesses found in the data collection process. Due to space limitations, we present only the most representative parts of the SWOT analysis, that is, the problems that need to be overcome in order to strategically direct IT. 
Table 3. Synthesis of Organization Alpha SWOT analysis results

\begin{tabular}{|c|c|c|c|}
\hline Theme & Perspective & Weaknesses & Involvement \\
\hline Cost control & Financial & $\begin{array}{l}\text { Costs allocation is done by IT } \\
\text { leader, without alignment with } \\
\text { strategic business priority } \\
\text { Costs allocation do not reflect IT } \\
\text { expansion and flexibility strategic } \\
\text { priorities } \\
\text { Processes for monitoring costs } \\
\text { and returns are absent }\end{array}$ & $\begin{array}{l}\text { Commercial } \\
\text { Director } \\
\text { Administrative } \\
\text { Director } \\
\text { Industrial } \\
\text { Director } \\
\text { IT Manager }\end{array}$ \\
\hline Service quality & Customers & $\begin{array}{l}\text { Low understanding of how IT can } \\
\text { be involved in changes within } \\
\text { organizational units } \\
\text { Deficiencies in defining priorities } \\
\text { for changes according to business } \\
\text { strategies } \\
\text { Low involvement of customer } \\
\text { areas during definitions of scope } \\
\text { and quality requirements in IT } \\
\text { projects } \\
\text { High incidences of rework on } \\
\text { projects due to inaccurate scope } \\
\text { specification }\end{array}$ & $\begin{array}{l}\text { Quality } \\
\text { Manager } \\
\text { Planning and } \\
\text { Production } \\
\text { Manager } \\
\text { IT Manager }\end{array}$ \\
\hline $\begin{array}{l}\text { Internal } \\
\text { Organization }\end{array}$ & Internal & $\begin{array}{l}\text { Unclear definition of } \\
\text { responsibilities within IT function } \\
\text { Reactive approaches in treating IT } \\
\text { incidents } \\
\text { Lack of information about IT } \\
\text { infrastructure due to an ad-hoc } \\
\text { configuration management }\end{array}$ & IT Manager \\
\hline $\begin{array}{l}\text { Competences } \\
\text { and } \\
\text { communication }\end{array}$ & $\begin{array}{l}\text { Learning and } \\
\text { growth }\end{array}$ & $\begin{array}{l}\text { Minimal knowledge of IT relating } \\
\text { to strategic priorities for effort } \\
\text { directing } \\
\text { IT staff lacks clear knowledge of } \\
\text { the strategic priorities of the } \\
\text { business }\end{array}$ & $\begin{array}{l}\text { IT Manager } \\
\text { Quality } \\
\text { Manager } \\
\text { Planning and } \\
\text { Production } \\
\text { Manager }\end{array}$ \\
\hline
\end{tabular}

Phase 3. IT strategic planning. Considering IT goals to be achieved (phase 1) and major deficiencies of IT to such achievement (phase 2), phase 3 execution defined strategic maps for IT followed by performance actions and indicators.

The IT strategic map for Organization Alpha starts from the learning and growth perspective in order to provide conditions for the proper development and execution of critical processes that will deliver value to the business units. Once effectively and efficiently executed, these processes could ensure responsiveness to production and quality control demands that, in turn, will support top management demands for expansion and cost control. 
Figure 1 illustrates the strategic map developed for Organization Alpha.

Objectives

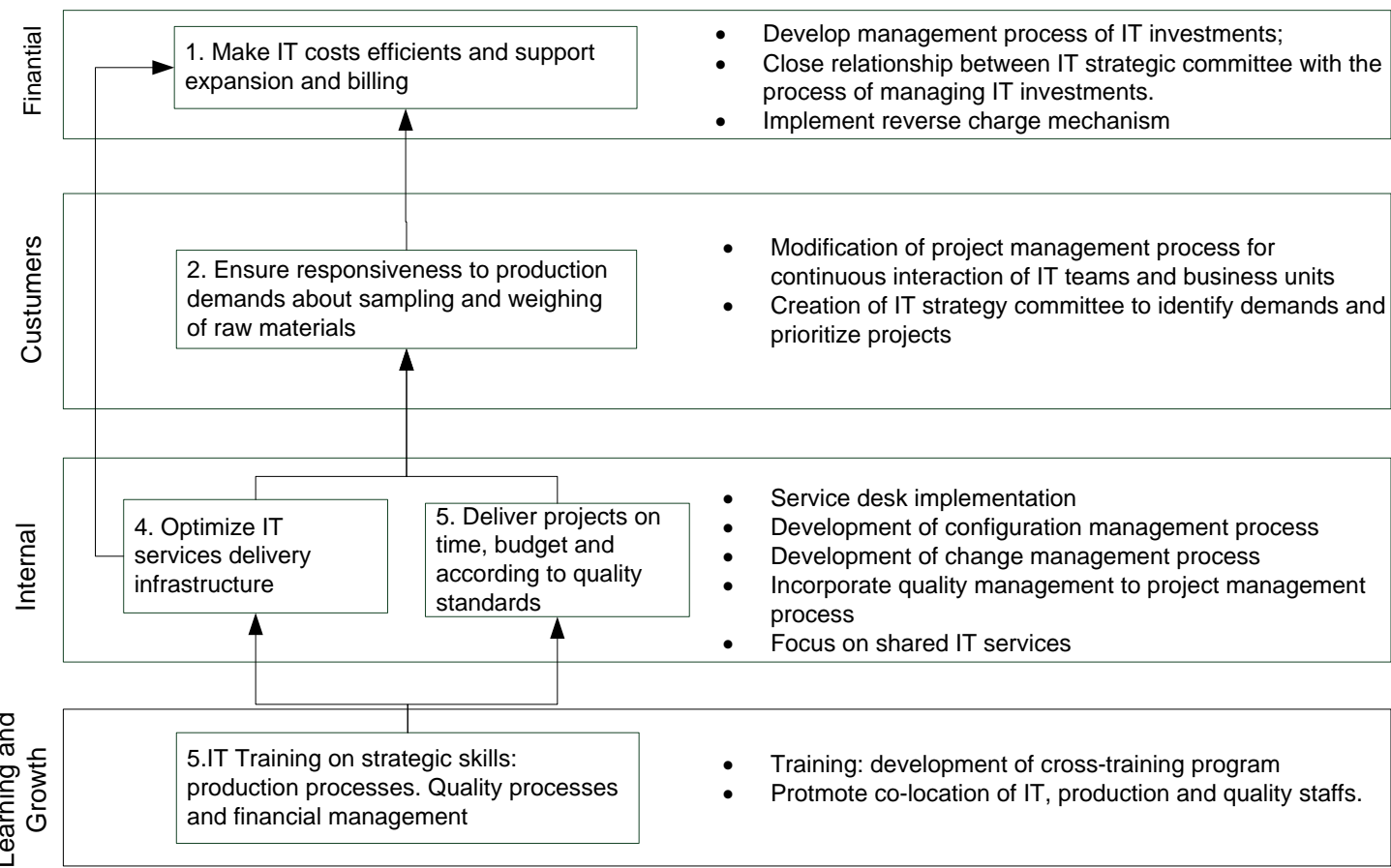

Figure 1. IT strategic map of Alpha Organization

Following the creation of the strategic map, indicators associated with IT goals were developed. Figure 2 illustrates the set of indicators and cause-effect relationship developed in the organization. For confidentiality purposes, we do not include the financial perspective.

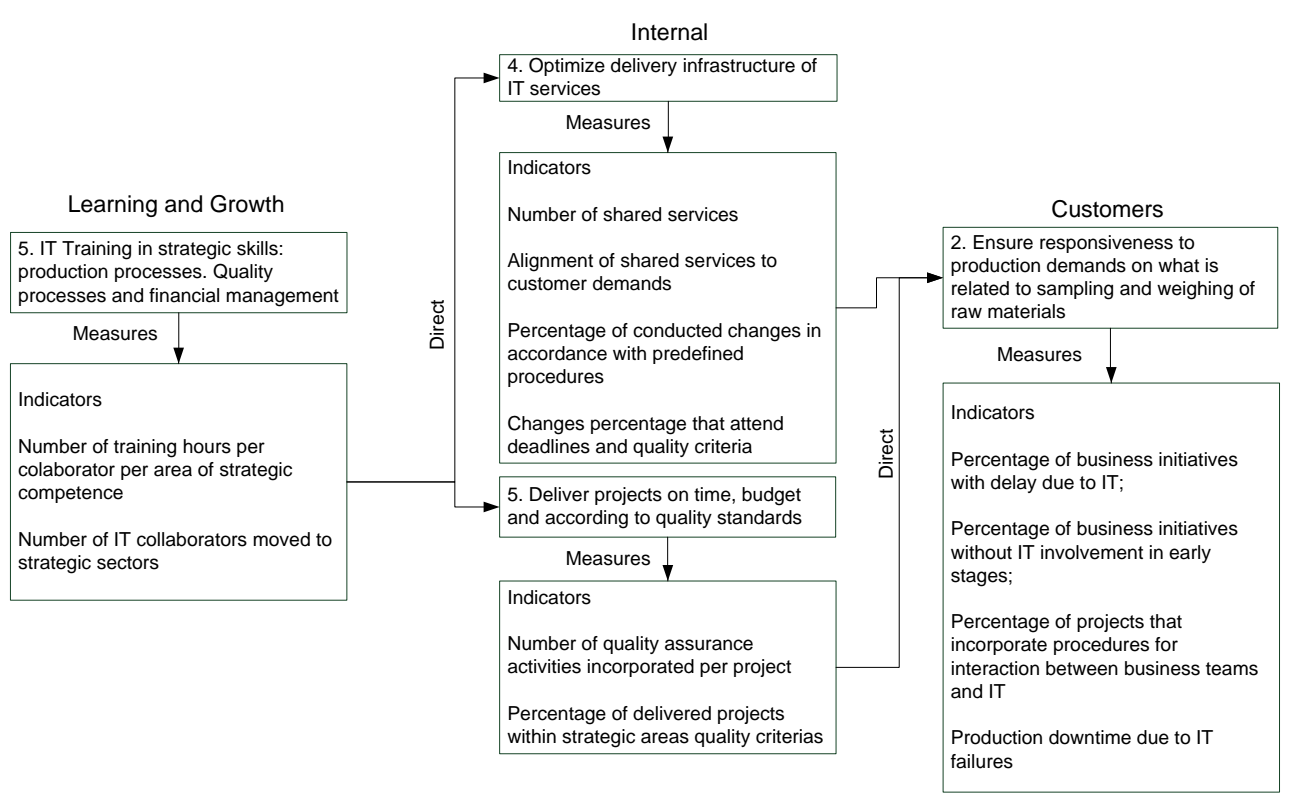

Figure 2.Organization Alpha strategic map and IT indicators 
Based on the results obtained in phase 3, synergy between IT and other areas in the organization were identified. In Organization Alpha, synergies were raised between IT function, production and quality sectors, and top management. Table 4 describes the synergies defined in Organization Alpha.

Table 4. Synergies defined on Organization Alpha

\begin{tabular}{|c|c|c|}
\hline $\begin{array}{l}\text { Synergy } \\
\text { IT }+ \\
\text { Production }\end{array}$ & Description & Related perspective \\
\hline \multirow{4}{*}{$\begin{array}{l}\text { IT }+ \\
\text { Production }\end{array}$} & Joint development of training program & Learning and Growth \\
\hline & $\begin{array}{l}\text { Identification of services that are } \\
\text { candidate for shared IT services }\end{array}$ & Internal \\
\hline & $\begin{array}{l}\text { Composition of IT project team for } \\
\text { Production Sector }\end{array}$ & Customers \\
\hline & Interaction by strategic committee & Customers \\
\hline $\begin{array}{l}\text { IT + Top } \\
\text { Management }\end{array}$ & $\begin{array}{l}\text { Interaction by strategic committee } \\
\text { Announcement of } \quad \text { new strategic } \\
\text { priorities for cost allocation and } \\
\text { investments prioritization }\end{array}$ & Financial \\
\hline
\end{tabular}

These interaction profiles were considered in phase 4 when projects for tactical plan composition were defined.

\section{Organization Beta}

Organization Beta, a fictitious name applied for confidentiality, acts in the private health care sector. Business operations in the organization are strongly regulated by the Health National Agency, especially with regard to pricing, accounting, and how customers' health information is handled.

Phase 1: IT alignment to business. During the execution of phase 1, the following stakeholders were involved: 1) CEO, CFO, and juridical departments, to support definitions in financial perspectives and to make appointments of strategic areas in the organization; 2) general management, exchange and proceedings area, and accounting (customer perspective); and 3) information technology management (internal perspectives and learning and growth). Table 5 illustrates BSC initial development in Organization Beta, considering the involvement of different stakeholders. 
Table 5. IT initial BSC in Organization Beta

\begin{tabular}{|c|c|c|}
\hline Event & Involvement & Results \\
\hline $\begin{array}{l}\text { Startup } \\
\text { meeting }\end{array}$ & $\begin{array}{l}\text { IT }+ \text { Top } \\
\text { Management }\end{array}$ & $\begin{array}{l}\text { Main focus: Ensure compliance with regulatory } \\
\text { requirements in the health sector } \\
\text { Prioritize strategic areas for compliance: general } \\
\text { management, juridical sector, and exchange and } \\
\text { authorizing }\end{array}$ \\
\hline ITVision & $\begin{array}{l}\text { Top Management } \\
+ \text { Strategic Areas } \\
+ \text { IT }\end{array}$ & $\begin{array}{l}\text { Ensure conformity of IT with regulations } \\
\text { regarding health information protection }\end{array}$ \\
\hline \multirow[t]{3}{*}{$\begin{array}{l}\text { IT } \\
\text { objectives }\end{array}$} & $\begin{array}{l}\text { Top Management } \\
+ \text { IT }\end{array}$ & $\begin{array}{l}\text { Financial perspective: } \\
\text { Minimize financial impacts arising from service } \\
\text { interruption and related penalties } \\
\text { Reduce financial losses arising from service } \\
\text { interruption }\end{array}$ \\
\hline & $\begin{array}{l}\text { Exchange and } \\
\text { Authorizing + IT }\end{array}$ & $\begin{array}{l}\text { Customers perspectives: } \\
3 \text {. Ensure protection of sensitive information } \\
\text { related to authorization of health services and } \\
\text { accounting } \\
\text { 4. Promote awareness of and training on health } \\
\text { information security }\end{array}$ \\
\hline & $\begin{array}{l}\text { IT }+ \text { Strategic } \\
\text { areas }\end{array}$ & $\begin{array}{l}\text { Internal perspective: } \\
5 \text {. Ensure, through web services and IT } \\
\text { management practices, security in transactions } \\
\text { involving health information } \\
6 \text {. Ensure continuity of systems that support } \\
\text { transactions associated with billing and health } \\
\text { information processing } \\
\text { 7. Create close ties between human resource } \\
\text { management and information security } \\
\text { management } \\
\text { Learning and growth perspective: } \\
\text { 8. Improve IT staff competencies associated with } \\
\text { IT service delivery. } \\
\text { 9. Improve employees' competencies associated } \\
\text { within formation security. }\end{array}$ \\
\hline
\end{tabular}

Phase 2: Capacity and performance analysis. In this phase, strengths, weaknesses, opportunities, and threats were gathered, and the following issues were considered: 1) treatment of regulations related to health information protection and services continuity (financial perspective); 2) IT services delivered to authentication, authorization and accounting (customers' perspective); 3) relationship between IT areas and human resources on what is relevant to information security issues related to people (customers' perspective); 4) IT internal processes and resources for delivering IT services related to the organization's strategic areas (internal perspective of learning and growth). 
Table 6 shows a sample of Organization Beta SWOT analysis results, considering major weaknesses found during data collection.

Table 6. Beta Organization SWOT analysis results synthesis

\begin{tabular}{|c|c|c|c|}
\hline Theme & Perspective & Weaknesses & Involvement \\
\hline $\begin{array}{l}\text { Compliance } \\
\text { treatment }\end{array}$ & Financial & $\begin{array}{l}\text { Low understanding about the } \\
\text { current status of the } \\
\text { organization's compliance with } \\
\text { legal requirements } \\
\text { Weak alignment between top } \\
\text { management, IT function, and } \\
\text { general management to meet new } \\
\text { legal requirements }\end{array}$ & $\begin{array}{l}\text { Executive } \\
\text { Director } \\
\text { Financial } \\
\text { Director } \\
\text { Juridical } \\
\text { Department }\end{array}$ \\
\hline $\begin{array}{l}\text { IT services } \\
\text { delivery }\end{array}$ & Customers & $\begin{array}{l}\text { Weak interaction between IT } \\
\text { function and other organizational } \\
\text { units to define IT services levels } \\
\text { Lack of mechanisms to monitor } \\
\text { IT service delivery to } \\
\text { organizational units }\end{array}$ & $\begin{array}{l}\text { Exchange } \\
\text { Authorization } \\
\text { Accountability }\end{array}$ \\
\hline $\begin{array}{l}\text { Relationship } \\
\text { with HR }\end{array}$ & Customers & $\begin{array}{l}\text { Low understanding of } \mathrm{HR} \\
\text { management on what information } \\
\text { must be protected } \\
\text { Essential technical focus of IT } \\
\text { regarding information security. }\end{array}$ & $\begin{array}{l}\text { Human } \\
\text { Resources }\end{array}$ \\
\hline $\begin{array}{lr}\text { Internal } & \text { IT } \\
\text { process } & \text { and } \\
\text { resources } & \end{array}$ & $\begin{array}{l}\text { Internal } \\
\text { Learning and } \\
\text { growth }\end{array}$ & $\begin{array}{l}\text { IT leadership with essentially } \\
\text { technical capacity and weak } \\
\text { interdisciplinary competencies } \\
\text { Reactive approach in dealing with } \\
\text { IT service continuity concerns } \\
\text { Low interaction with } \\
\text { organizational units and top } \\
\text { management to discuss and treat } \\
\text { new compliance requirements }\end{array}$ & $\begin{array}{l}\text { Information } \\
\text { Technology }\end{array}$ \\
\hline
\end{tabular}

\section{Phase 3. IT strategic planning}

Based on IT goals to be achieved (phase 1) and on major IT deficiencies identified (phase 2), in phase 3, the strategic map was defined for Organization Beta. The strategic map developed for Organization Beta starts from the learning and growth perspective to create the necessary conditions - staff capabilities and interaction among organizational units - to conduct internal processes with required levels of information security. 
Figure 3 shows the strategic map developed on Beta Organization.

Objectives

Strategic actions

\begin{tabular}{|c|c|c|}
\hline $\begin{array}{l}\text { Minimize financial } \\
\text { impacts arising from } \\
\text { regulations non- } \\
\text { compliance }\end{array}$ & $\begin{array}{l}\text { Minimize financial losses } \\
\text { resulting from } \\
\text { interruption of health } \\
\text { procedures authorization } \\
\text { services }\end{array}$ & $\begin{array}{l}\text { - Develop performance monitoring mechanism in information } \\
\text { security and treatment to compliance }\end{array}$ \\
\hline \multicolumn{3}{|c|}{$\Lambda$} \\
\hline \multicolumn{2}{|c|}{$\begin{array}{l}\text { Ensure protection of sensitive information on } \\
\text { systems that support authorization, } \\
\text { accounting and exchange process; }\end{array}$} & $\begin{array}{l}\text { - Consolidate information security committee : alignment } \\
\text { between identification of requirements compliance with HR } \\
\text { management and management and processes of IT services } \\
\text { - Implementing information security management process in HR }\end{array}$ \\
\hline \multicolumn{3}{|c|}{4} \\
\hline $\begin{array}{l}\text { Systems to ensure } \\
\text { continuity of } \\
\text { transactions involving } \\
\text { billing and health } \\
\text { information }\end{array}$ & $\begin{array}{l}\text { Ensure, through use of } \\
\text { web services and } \\
\text { management practices, } \\
\text { safety in transactions } \\
\text { involving health } \\
\quad \text { information; }\end{array}$ & $\begin{array}{l}\text { - Implement service desk and incident management for security } \\
\text { and continuity } \\
\text { - Implement service level managing process for security and } \\
\text { continuity }\end{array}$ \\
\hline \multicolumn{3}{|c|}{$\Delta$} \\
\hline \multicolumn{2}{|c|}{$\begin{array}{l}\text { Develop closer links with management of human } \\
\text { resources for information security management }\end{array}$} & \multirow{2}{*}{$\begin{array}{l}\text { - Creation of information security committee: identification and } \\
\text { reporting of compliance requirements for security } \\
\text { - Consultancy for training IT teams } \\
\text { - } \quad \text { Environs-training. } \\
\text { strategic areas. }\end{array}$} \\
\hline $\begin{array}{l}\text { Training IT staff in } \\
\text { service management } \\
\text { and IT security }\end{array}$ & $\begin{array}{l}\text { Training of employees in } \\
\text { information security } \\
\text { procedures. }\end{array}$ & \\
\hline
\end{tabular}

Figure 3. IT strategic map of Organization Beta

Following the creation of strategic maps, indicators associated with IT goals were developed. Figure 4 shows the set of indicators and the cause-effect relationship developed in Organization Beta.

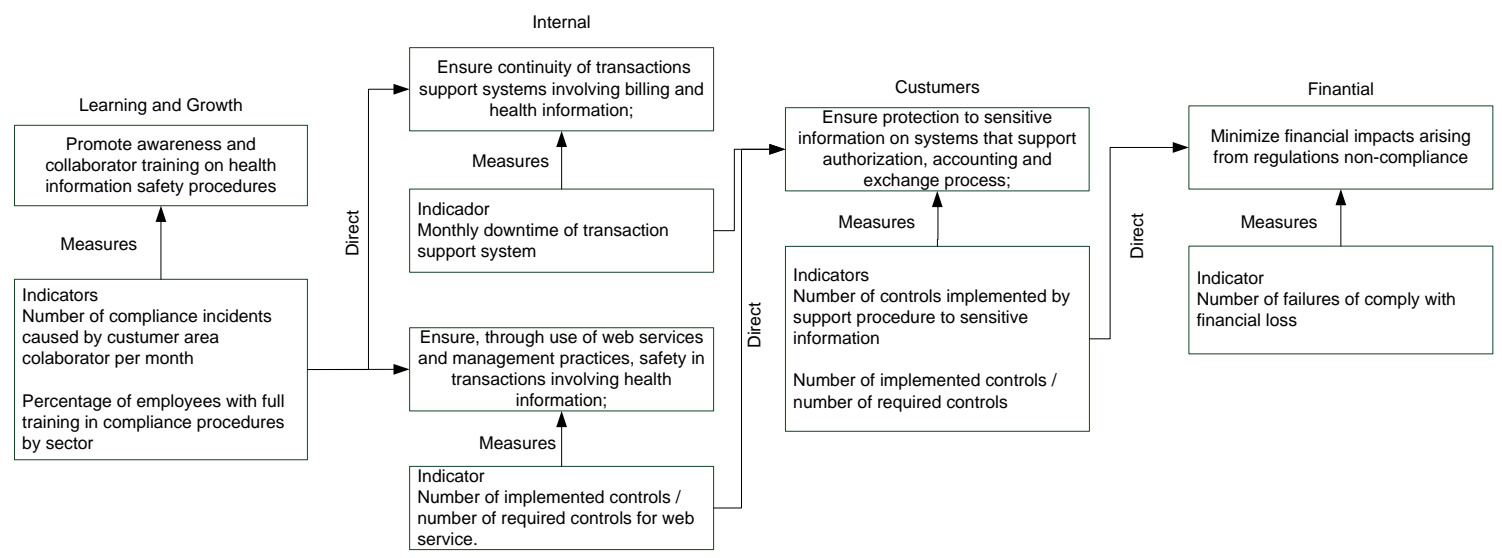

Figure 4. Strategic map and IT indicators on Beta Organization 
In phase 3, synergies with different organizational units-juridical, exchange and authorization of health proceedings, human resources, and top management sectors - were observed. Table 7 shows the synergies observed in this phase.

Table 7. Description of synergies defined in Organization Beta

\begin{tabular}{|c|c|c|}
\hline Synergy & Description & Related perspective \\
\hline \multirow[t]{3}{*}{$\begin{array}{l}\text { IT }+ \text { Exchange } \\
\text { and } \\
\text { Authorization }\end{array}$} & $\begin{array}{l}\text { Development of a training program for } \\
\text { information security and IT service } \\
\text { level management }\end{array}$ & Learning and growth \\
\hline & $\begin{array}{l}\text { Interaction for compliance requirement } \\
\text { impact analysis }\end{array}$ & Customers \\
\hline & Development of IT service levels & Internal \\
\hline IT + Juridical & $\begin{array}{l}\text { Identification and analysis of } \\
\text { compliance requirements }\end{array}$ & Customers \\
\hline $\mathrm{IT}+\mathrm{HR}$ & $\begin{array}{l}\text { Definition and maintenance of } \\
\text { information security processes for HR }\end{array}$ & Customers \\
\hline
\end{tabular}

As in Organization Alpha, these interaction profiles for Organization Beta were considerate in phase 4 , when projects to tactical plan were defined.

\section{CONCLUSIONS AND FURTHER RESEARCH}

In this paper, we propose a method that integrates IT strategic planning and Balanced Scorecard concepts in order to provide a systematic approach to direct IT in alignment with strategic business priorities.

The application of the proposed method in two organizations showed that the integration between BSC and ITSP can contribute to the expansion of ITSP over IT frontiers and involve both business units and top management. The results show that the definition of balanced perspectives in the method contributed to the identification and involvement of relevant stakeholders that are outside the IT function. Therefore, based on the two case studies, we conclude that the proposed method can be an instrument that contributes to expansion of IT frontiers (Grover \& Segars, 2005), and it can mitigate the excessive focus on IT internal aspects and decrease the use of multidisciplinary teams (Earl, 2003).

The main contributions of this study are, through the proposed method, the clarification of how to incorporate the Balanced Scorecard in an IT strategic planning effort. Through a presentation and application of an ITSP method that incorporates balanced scorecard concepts, this work provides guidelines to mitigate common IT strategic planning challenges, such as the expansion of ITSP frontiers and the interaction between IT and other organizational units in the planning process. The two case studies show that the incorporation of BSC provides synergies between different groups (such as Top Management, IT, and Exchange and Authorizing Area) in the development of key activities to strategically direct IT in both organizations. These 
synergies were possible, in part, due to the need to consider the different perspectives from which IT strategies and actions can be described, including customers, financial, internal processes, and learning and growth.

In this way, this work extends the contributions provided by contributes to Segars and Grover's (2005) with respect to ITSP process definition and comprehending how it can provide satisfactory results. The alignment between BSC and ITSP offers a systematic approach that guides the definition of IT directions in alignment with business units and strategic priorities. The proposed method provides generic guidelines that organizations can use to incorporate balanced scorecard concepts in the ITSP. Then, they can create an environment that is more conductive to the necessary synergies between groups when developing IT strategies that are aligned with the business.

However, the method itself is not a sufficient condition to overcome ITSP challenges. Skilled people, organizational culture, and other factors also exert significant influence and must be investigated in future works.

This study has some natural limitations in terms of study focus. Two organizations were studied; however, these findings cannot be used to generalize the results and conclusions obtained from this study to any other specific organization. Moreover, this work is limited to ITSP development and does not cover implementation from developing strategies outside of the ITSP process. As one aim of this study is to establish an understanding of the applicability of BSC on ITSP, the following future studies are proposed.

Future works can expand the context of the proposed method to other organizations and contexts, aiming to deepen the understanding of balanced scorecard applicability on ITSP. Additionally, future researchers can adopt a quantitative approach to define and test hypotheses about BSC application on ITSP. Finally, future works can evaluate the implementation results of IT strategic plans developed using balanced scorecard concepts. Such studies can be relevant to evaluate the contributions of BSC for approximating IT strategies, implementation, and planning activities.

\section{Acknowledgements}

The authors thank the National Council of Technological and Scientific Development (CNPq - Brazil), Coordination for the Improvement of Higher Level Personnel (Capes - Brazil), and the Foundation for Research Support of the State of Minas Gerais (FAPEMIG - Brazil) for the financial support.

A prior version of this paper was presented at the $9^{\text {th }}$ International Conference on Information System and Technology Management (CONTECSI) in 2010 in São Paulo, Brazil. The authors also thank the double-blind reviewers of this conference. 


\section{REFERENCES}

Bechor, T., Neumann, S., Zviran, M., Chanan, G., \& (2010). A contingency model for estimating success of strategic information systems Planning. Information \& Management., 47(1), 17-29.

Bermejo, P. H. S., Tonelli, A. O., Brito, M., J., \& Zambalde, A. L. (2012).Implementation of information technology governance through IT strategic planning. African Journal of Business Management, 6: 11179-11189.

Boar, B. H. (1994).Practical steps for aligning information technology with business strategies: how to achieve a competitive advantage. New York: John Wiley.

Broady-Preston, J., \& Hayward, T. E. (1998).An assessment of the relationship between marketing, information and strategy formulation in the retail banking sector. International Journal of Information Management, 18(4), 277-285.

Cerpa, N., \& Verner, J. M. (1998). Case study: The effect of IS maturity on information systems strategic planning. Information \& Management, 34(2), 199-208. .

Earl, M. J. (2003). Approaches to information systems planning. Experiences in strategic information systems planning. In R. D. Galliers \& D. E. Leidner (Eds.), Strategic information management: challenges and strategies in managing information systems (Third ed.). Burlington: Elsevier.

Gimbel, S. (1968).Exploring the Scientific Method: Cases and Questions. London: The University of Chicago Press.

Grover, V., \& Segars, A. H. (2005). An empirical evaluation of stages of strategic information systems planning: patterns of process design and effectiveness. Information \& Management, 42(5), 761-779.

Gutierrez, A., \& Serrano, A. (2008). Assessing Strategic, Tactical, and Operational Alignment Factors for SMEs: Alignment Across the Organisation's Value Chain. International Journal of Value Chain Management, 2(1), 33-56.

Heckman, R. (2003). Strategic Information Technology Planning and the Line Manager's Role. Information Systems Management 20(4), 16-21.

Huang, C., \& Hu, Q. (2007).Achieving IT-business strategic alignment via enterprisewide implementation of balanced scorecards. Information Systems Management 24(2), 173-184.

ITGI, I. G. I. (2007).COBIT 4.1: control objectives, management guidelines, maturity models. Rolling Meadows: ITGI.

Jung, C. F. (2004). Metodologia para pesquisa \& desenvolvimento aplicada a novas tecnologias, produtos e processos. Rio de Janeiro: Axcel Books do Brasil.

Kaplan, R. S., \& Norton, D. P. (1997). A estratégia em ação: balanced scorecard (22th ed.). Rio de Janeiro: Elsevier. 
Kaplan, R. S., \& Norton, D. P. (2008). A Execução Premium: A obtenção de vantagem competitiva através do vínculo da estratégia com as operações de negócio. Rio de Janeiro: Elsevier.

Keyes, J. (2005). Implementing the IT Balanced Scorecard: Aligning IT with Corporate Strategy. Boca Raton: Auerbach Publications.

Lederer, A. L., \& Salmela, H. (1996).Toward a theory of strategic information systems planning.Journal of Strategic Information Systems, 5(3), 237-253.

Lederer, A. L., \& Sethi, V. (2003). The Information Systems Planning Process: Meeting the challenges of information systems planning. In R. D. Galliers \& L. D. E. (Eds.), Strategic information management: challenges and strategies in managing information systems United Kingdom: Elsevier.

Lee, G. G., \& Bai, R. J. (2003). Organizational Mechanisms for successful IT/IS strategic planning in the digital era. Management Decision, 41(1), 32-42.

Lee, G. G., \& Pai, R. J. (2003).Effects of organizational context and inter-group behaviour on the success of strategic information systems planning: an empirical study. Behaviour and Information Technology, 22(4), 263-280.

Littler, K., Aisthorpe, P., Hudson, R., \& Keasey, K. (2000). A new approach to linking strategy formulation and strategy implementation: an example from the UK banking sector. International Journal of Information Management, 20, 411-428.

Lutchen, M. D. (2004). Managing IT as a business: a survival guide for CEOs. Hoboken: John Wiley \& Sons.

Mentzas, G. (1997). Implementing is an strategy: a team approach. Long Range Planning, 30(1), 84-95.

Min, S. K., Suh, E. H., \& Kim, S. Y. (1999).An integrated approach toward strategic information systems planning. Journal of Strategic Information Systems, 8(4), 373-394.

Newkirk, H. E., L., L. A., \& Srinivasan, C. (2003). Strategic information systems planning: too little or too much. Journal of Strategic Information Systems, 12(3), 201228.

Niven, P. (2002). Balanced Scorecard Step by Step: Maximizing Performance and Maximizing Results. New York: John Wiley \& Sons.

Pai, J. C. (2006). An empirical study of the relationship between knowledge sharing and IS/IT strategic planning (ISSP). . Management Decision, 44(1), 105-122.

Salmela, H., \& Spil, T. A. M. (2002).Dynamic and emergent information systems strategy formulation and implementation. International Journal of Information Management, 22, 441-460.

Segars, A. H., \& Grover, V. (1998). Strategic information systems planning success: an investigation of the construct and its measurement. MIS Quarterly, 22(2), 139-163.

Simon, P. P. (2011). Design and implementation of the Balanced Scorecard at a university institute. Measuring Business Excellence, 15(3), 34 - 45. 
Van Grembergen, W., \& De Haes, S. (2005). Measuring and Improving IT Governance Through the Balanced Scorecard. Information Systems Control Journal 2.

Velcu, O. (2010). Strategic alignment of ERP implementation stages: An empirical investigation. Information \& Management, 47(3), 158-166.

Yin, R. (2005). Estudo de caso: planejamento e métodos (Third ed.). São Paulo: Artmed. 